\title{
SERVICEABILITY FRAGILITY FUNCTIONS FOR NEW ZEALAND RESIDENTIAL WINDOWS
}

\author{
David M. Carradine ${ }^{1}$, Aman Kumar ${ }^{2}$, Roger Fairclough ${ }^{3}$ and \\ Graeme Beattie ${ }^{4}$
}

(Submitted November 2019; Reviewed March 2020; Accepted June 2020)

\begin{abstract}
Glazing and window systems in New Zealand have been shown to be susceptible to significant damage as evidenced by the past decade of earthquakes. The seismic performance of glazing and window systems has resulted in considerable financial loss, disruption in business and physical injuries following earthquakes. In order to investigate the vulnerability of residential windows in typical light timber framed buildings racking testing was conducted on six wall configurations. Numerous observations of window performance were made during the testing and from these results fragility functions were developed for timber and aluminium framed windows. These fragility functions suggest that even at low displacement levels damage can occur to windows that can potentially affect weather-tightness and require repairs following an earthquake. These functions can inform decisions around designing for resiliency in residential structures in New Zealand.
\end{abstract}

\section{INTRODUCTION}

Glazing and window systems in New Zealand have been shown to be susceptible to significant damage as evidenced by the past decade of earthquakes. The seismic performance of glazing and window systems has resulted in considerable financial loss, disruption in business and physical injuries following earthquakes. Following the 2011 Canterbury Earthquake a survey of 217 multi-storey buildings provided data that improvements are required to better understand how nonstructural systems including facades and windows perform during earthquakes and that design guidance is needed [1]. Dhakal [2] also described the damage to glazing and other nonstructural building elements resulting from the 2010 Darfield earthquake. Because windows and glazing tend to include large spans of brittle glass, they can be particularly susceptible to interstorey drifts which can lead to catastrophic failure resulting in buildings that no longer are protected from the elements, with consequential durability problems for both structural and nonstructural components. BRANZ research [3-5] provided some insight on the behaviour and evaluation of glazing systems for multi-storey buildings, but these were not applicable to typical residential windows. Research by O'Brien et al. [6] considered the fragility of glazing systems, but this also did not include examples representative of commonly used residential windows in New Zealand.

Residential window systems have also at times shown significant resilience with damaged buildings having windows surviving quite well following earthquakes even though the surrounding building was heavily damaged as seen in Figure 1. Full-scale testing on educational light timber frame buildings has shown that windows can provide significant lateral load resistance and can resist damage to the glass at significant drift levels [7].

The objectives for this research included experimental cyclic testing of three representative aluminium framed windows and three wooden framed windows and to develop fragility functions for each type as applied to residential buildings in New Zealand. Testing and analysis are described along with fragility function development and potential applications of the findings.

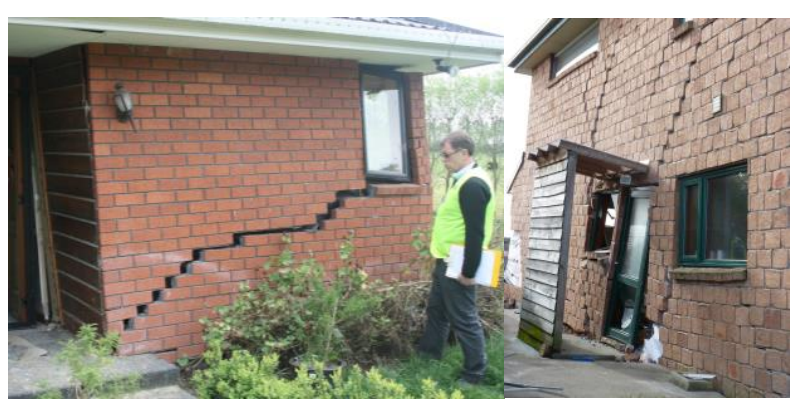

Figure 1: Damage to windows following Canterbury earthquakes.

\section{TEST SPECIMENS}

For the remainder of this report, any reference to aluminium windows refers to windows with aluminium framing and similarly for wooden windows. Two single-storey timber frames were constructed at BRANZ for testing of three representative aluminium windows and three wooden windows to find fragility curves for each type (Figure 2). The timber frames were assembled from 90 x 45 mm SG8 H1.2 kiln dried Radiata Pine. Every attempt was made to construct the frames and install the windows according to standard practice for residential buildings in New Zealand. The top and bottom plates were connected to the studs with two $90 \times 3.15 \mathrm{~mm}$ power-driven nails. The overall frame sizes were $2.4 \mathrm{~m}$ high $\mathrm{x}$ $3.0 \mathrm{~m}$ long with studs at $400 \mathrm{~mm}$ centres. No nogs were installed for these tests. Plasterboard linings were installed on the frames to provide stability to the frames. All windows were installed according to standard practice using NZS 3604 [8] and Carpentry [9] as guides. The timber frames were adjusted to accommodate the different window sizes for each type of tested window frame.

\footnotetext{
1 Corresponding Author, Senior Structural Research Engineer, BRANZ, Wellington, david.carradine@branz.co.nz (Member)

2 Fire Laboratory Technician, BRANZ, Wellington

3 Managing Director, Neo Leaf Global, Wellington

4 Technical Lead - Structural, Engineering Design Consultants, Whakatane, (Fellow)
} 


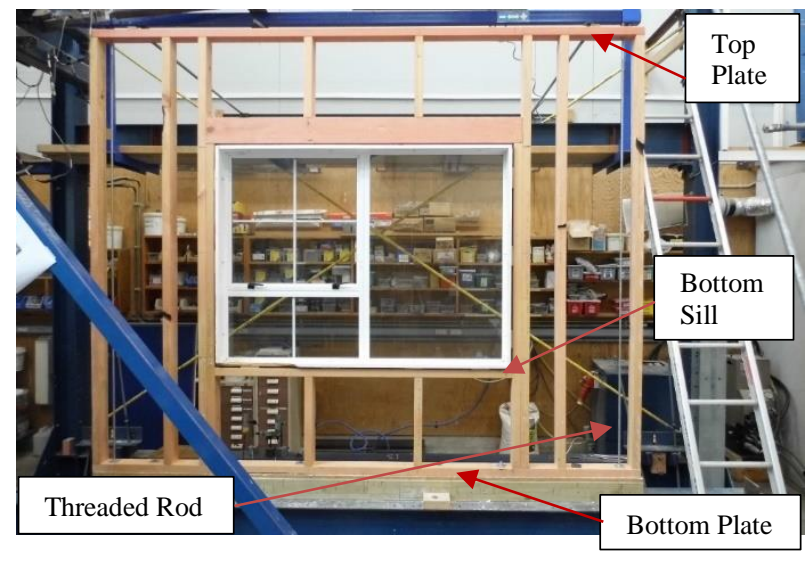

Figure 2: Typical timber frame with window installed prior to plasterboard installation.

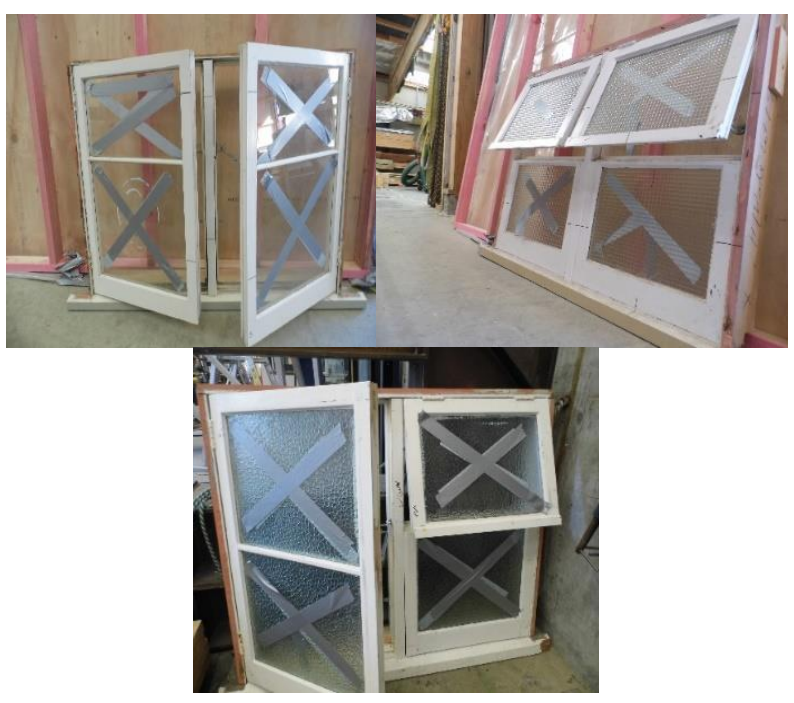

Figure 3: Wooden windows for residential fragility testing (Window 1 (Top Left): 1,290 mm wide x 1,030 mm high;

Window 2 (Top Right): 1,320 mm wide $x 990 \mathrm{~mm}$ high; Window 3 (Bottom): 1,325 mm wide $x 1,050 \mathrm{~mm}$ high).

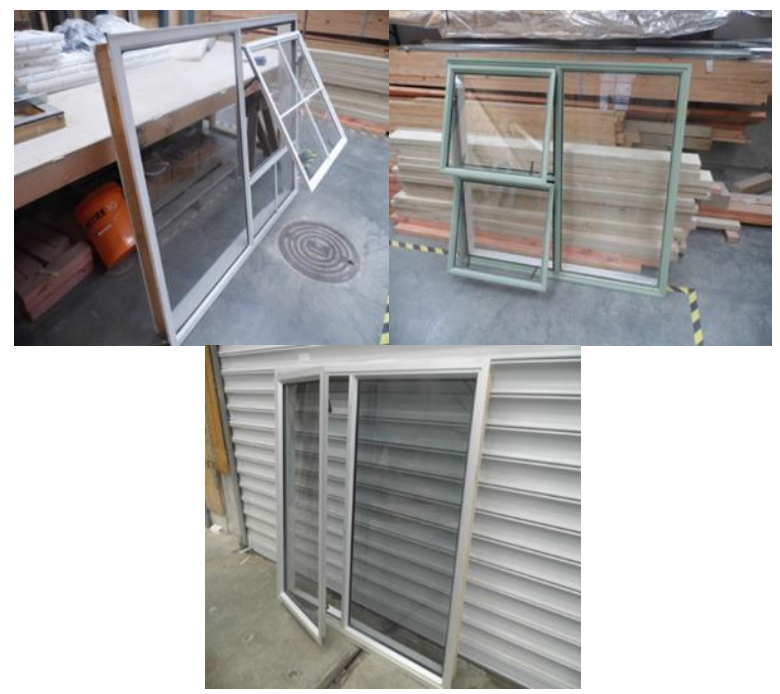

Figure 4: Aluminium windows for residential fragility testing (Window 1 (Top Left): 1,600 mm wide $x 1,200 \mathrm{~mm}$ high; Window 2 (Top Right): 1,202 $\mathrm{mm}$ wide $x 1,160 \mathrm{~mm}$ high; Window 3 (Bottom): 1,500 $\mathrm{mm}$ wide $x 1,250 \mathrm{~mm}$ high).
Six different windows were selected for the test, three wooden (Figure 3) and three aluminium (Figure 4). The window manufactures were not known as the windows were sourced from building recyclers in the Wellington region. Wooden window frames and sashes were made from unidentified timber but were very typical of commonly used New Zealand residential windows. All windows opened outwards. All aluminium windows had single pane glass with double and single openings.

There were some differences among test specimens due to the different sized windows. As noted, for each window type (timber and aluminium) a single timber framed wall was constructed and then modified for subsequent tests. New lintels and bottom sills were used for each test with studs being adjusted to accommodate the different windows. All window frames were fixed with $75 \mathrm{~mm} \times 3.15 \mathrm{~mm}$ stainless steel jolt head nails. Each window included 12 nails, which were installed at $150 \mathrm{~mm}$ from each corner, then one near the centre of each pane. Each fixing was packed apart from the lintel and frames as needed using timber packing.

\section{EXPERIMENTAL TESTING}

For each test the timber frame was installed in a rigid steel loading frame typically used for P21 bracing testing [10] as seen in Figure 2 and shown schematically in Figure 5. The bottom plates of the timber frames were secured to the test frame using $12 \mathrm{~mm}$ diameter threaded rods which were placed $100 \mathrm{~mm}$ in from each wall end such that the rods would line up with holes in the top plate. The threaded rods were installed through holes drilled through the bottom plates and secured with two nuts in order to represent a coach screw connection to a timber floor or an anchor bolt connection to a concrete floor. The rods then extended up through the top plate to serve as an uplift restraint in an effort to provide a more realistic overburden scenario. The bottom plates were also held down securely through a $20 \mathrm{~mm}$ layer of particleboard into a $120 \mathrm{~mm}$ x $120 \mathrm{~mm}$ timber beam using $12 \mathrm{~mm}$ x $120 \mathrm{~mm}$ coach screws. These coach screws were installed next to each stud in order to securely hold down the bottom plate and avoid lifting or sliding of the plates during testing.

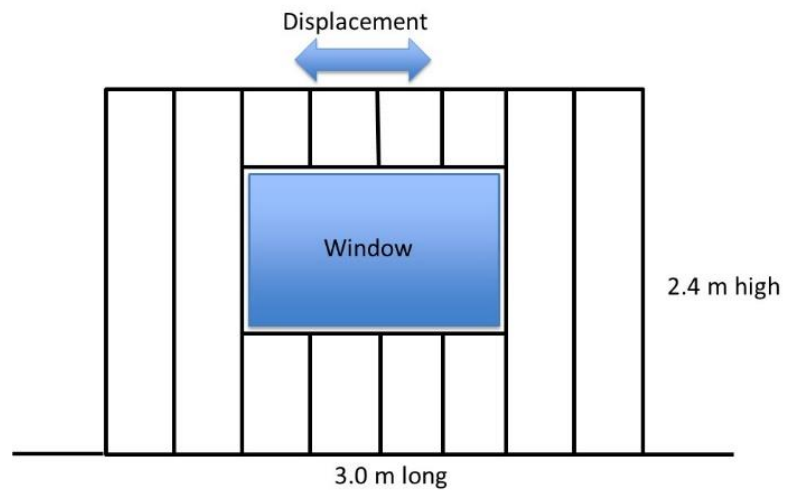

Figure 5: Schematic diaphragm of window testing within timber frame.

Once the timber frame was securely bolted down to the P21 frame, windows were installed as per standard practice. A gap of $20 \mathrm{~mm}$ was allowed for on the top and sides of the window openings. Each window was then installed directly on the bottom sill in the opening with packers to the top and two sides. Standard $10 \mathrm{~mm}$ thick plasterboard was nominally fixed at 150 $\mathrm{mm}$ centres around panel edges and $300 \mathrm{~mm}$ on intermediate studs for the region around the windows. Plasterboard was attached to one side of the timber framing using 6-gauge $\mathrm{x} 32$ $\mathrm{mm}$ long plasterboard screws. The full length of wall panel was assumed to provide bracing and therefore a more condensed 
screw pattern was used that was more typical for bracing plasterboard walls for the full-height end panels of each test specimen using plasterboard manufacturer specifications. Lintels were specified and installed according to NZS 3604 [8] requirements.

In-plane loads were applied to the centre of the specimen top plates using a $50 \mathrm{kN}$ closed loop servo-hydraulic actuator and loads were measured using a $25 \mathrm{kN}$ load cell. Out-of-plane movement of top plates was prevented by restraining rods typically used for P21 testing which allow movement in the plane of the wall but provide restraint against out-of-plane movement. These restraints were screwed to the top plates near the ends of the walls and tied back to the Laboratory wall. A linear potentiometer was used to measure the horizontal in plane displacement of the top plate. The test load and displacement measurements were recorded using a computercontrolled data acquisition system throughout each test.

Racking tests were performed using fully reversed cyclic displacements of the top plates. The displacements were sequentially increased using one cycle per displacement level in $1 \mathrm{~mm}$ increments, stopping at the peak of positive and negative displacement for each increment to observe and document any change in window behaviour. The $1 \mathrm{~mm}$ displacement increments were used up to the point where it could be observed that no additional damage was occurring to the windows and at this point the increments were increased to $5 \mathrm{~mm}$ or $10 \mathrm{~mm}$, depending on the specimen and observed damage. Cyclic loading was continued up to $70 \mathrm{~mm}$ displacement in the positive and negative directions for each specimen. All specimens were subjected to an additional monotonic push to top plate displacements of $+150 \mathrm{~mm}$.

\section{OBSERVATIONS DURING TESTING}

In general, the six tested window specimens responded similarly to the applied loading regime. The focus of this project was on the window performance and damage during testing, therefore observations were limited to the windows. The observations included gap openings in the window frames, jamming and inability of the windows to open, out of plane deflections of the windows and rotation of the window frames within the walls. It was assumed before testing that there would also be cracking of the glass panes and shattering of the windows, but this was only observed in one specimen, while the remaining five specimens were subjected to the full range of displacements up to $+150 \mathrm{~mm}$ without any obvious signs of glass failure.

Gaps in window framing began to occur early in the testing at small displacements, with jamming and inability of the windows to open occurring soon after that. The specimens tended to reach maximum loads and then continued to resist similar loads for many cycles. There tended to be increases in applied loads later during testing as the window frames jammed within the timber wall framing.

\section{RESULTS AND FRAGILITY FUNCTION DEVELOPMENT}

Load and displacement data recorded during testing allowed development of hysteresis plots for all specimens. Examples are provided for aluminium and timber windows in Figure 6 and Figure 7, respectively.

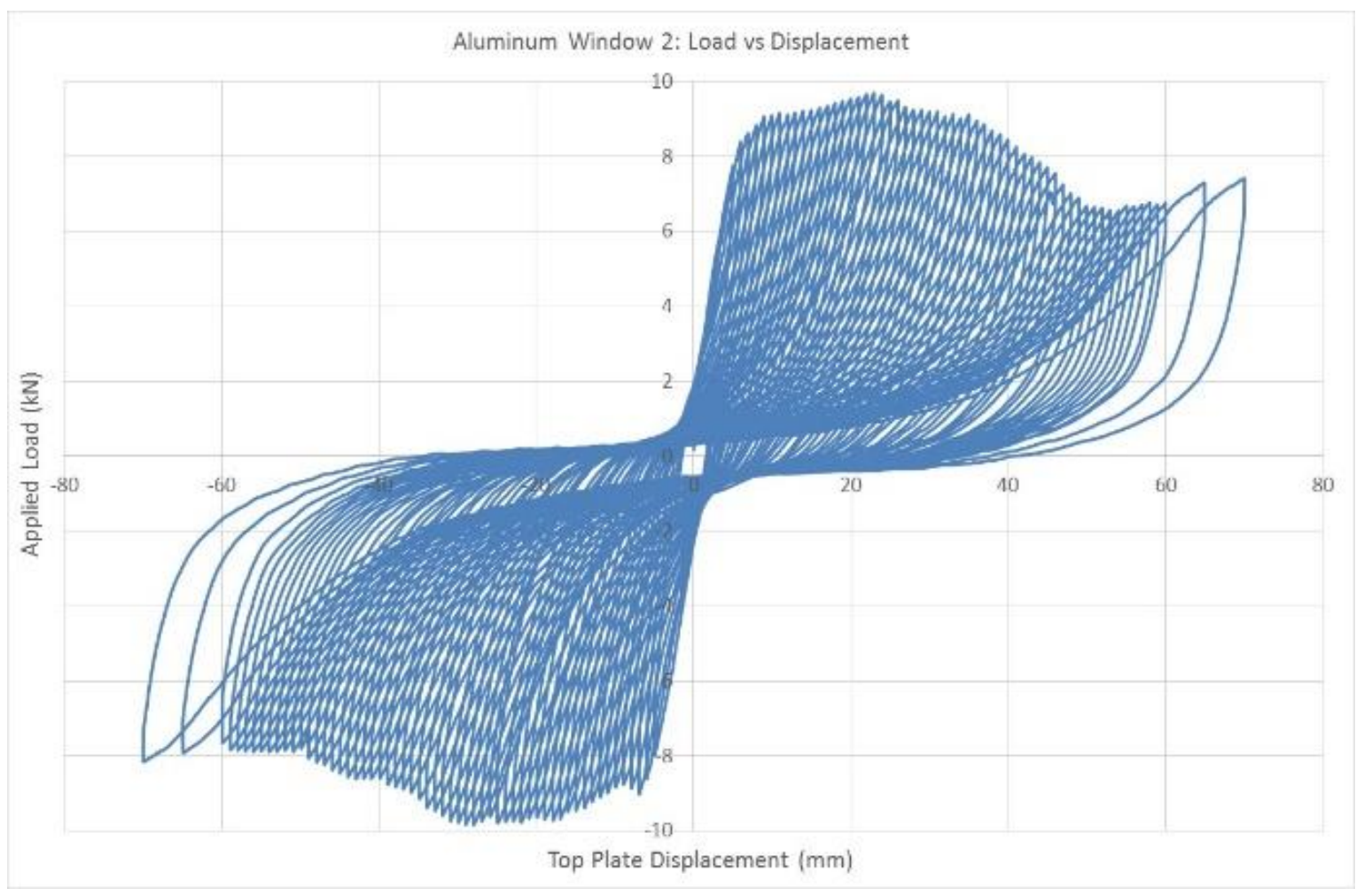

Figure 6: Typical hysteresis plot for aluminium window specimens. 


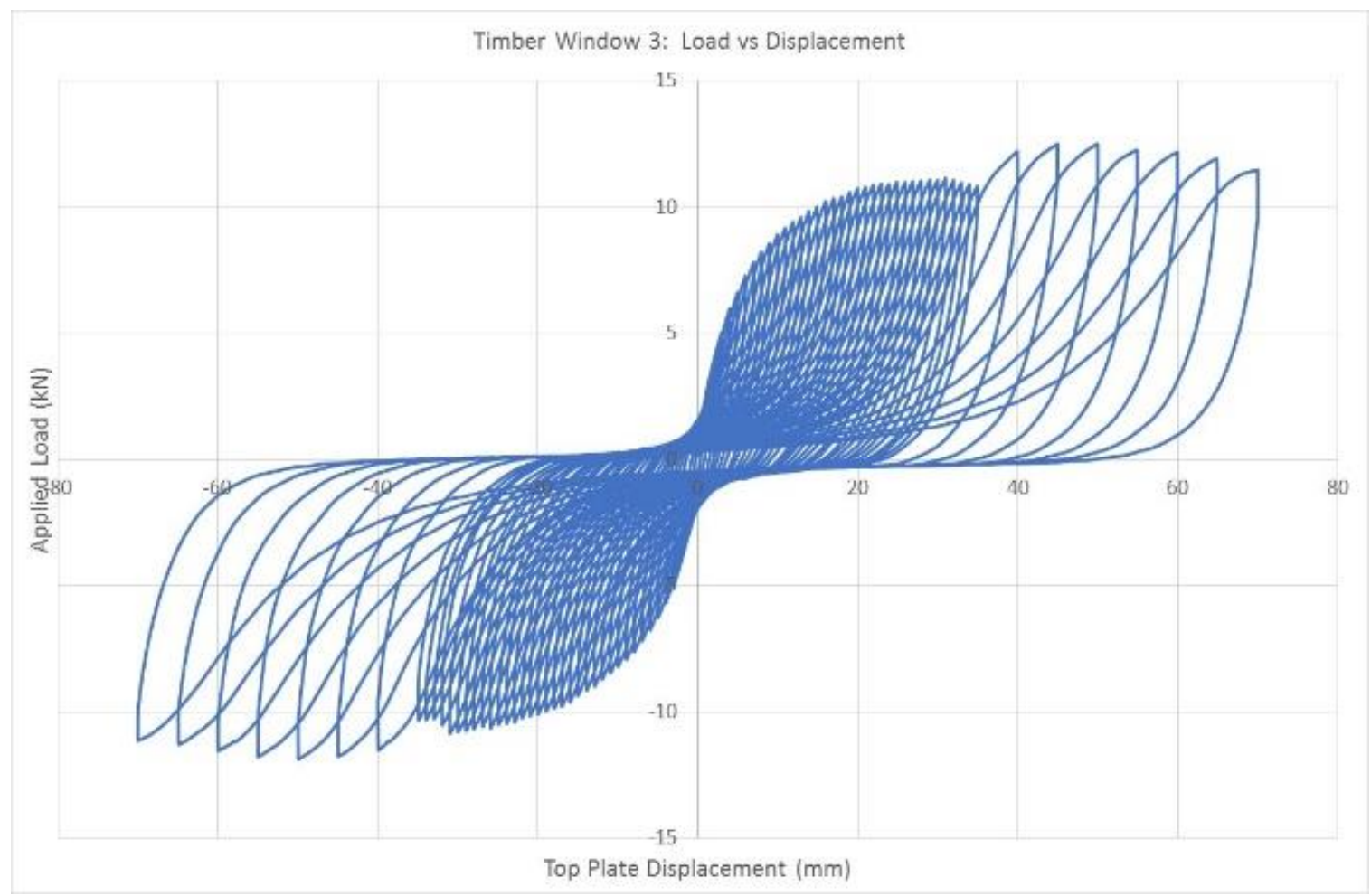

Figure 7: Typical hysteresis plot for timber window specimens.

Data gathered during testing on the damage to the windows resulting from the different levels of displacement were used to develop fragility functions for the two window types when used as elements within light timber frame wall systems. The method for fragility function development is described in Porter et al. [11], which provides six different methods depending on the type of data obtained and the number of specimens tested. Top plate displacement was converted to percentage drift and provided ample demand data throughout testing. With only three specimens of each type tested, the most appropriate method was Method A from, which required all specimens to reach the "failure" criteria and that the input demand could be correlated to the criteria occurrence. The fragility curve development equations for Method A are provided in Porter et al. [11] and include requirements for specimen replicate numbers and engineering demand parameters (displacement and corresponding drift in this case) used for the analysis.

Because there was only a single example of a broken window for the six tested specimens, it was decided that criteria for establishing fragility functions for these windows would have to be based more on serviceability rather than failure. The broken window failure occurred during testing of the first aluminium framed window and was a result of the monotonic push out to $150 \mathrm{~mm}$. The following criteria were established for each tested specimen and used to develop fragility functions for residential windows:

1. Observance of gaps in window frames that would potentially affect building weather tightness

2. Jamming or inability to open window panes that would require some repairs

3. Rotation of window frames within wall panel requiring more significant repairs.

Examples of Criteria 1 and Criteria 3 damage are shown in Figure 8 and Figure 9, respectively. Criteria 2 evaluations were conducted by attempting to open windows at the various displacement levels. For each test specimen the criteria were determined and correlated with resulting drift levels so that fragility functions could be derived using Method A [11] and are shown in Figure 10 for aluminium windows and Figure 11 for wooden windows. Table 1 provides data gathered and used for fragility curve development.

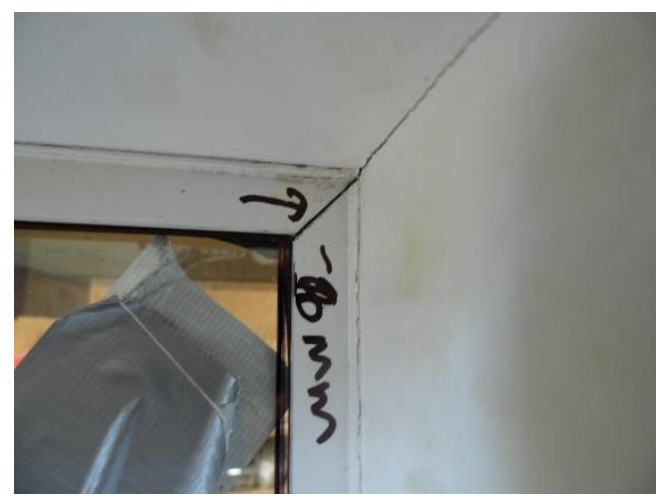

Figure 8: Example of Criteria 1 damage.

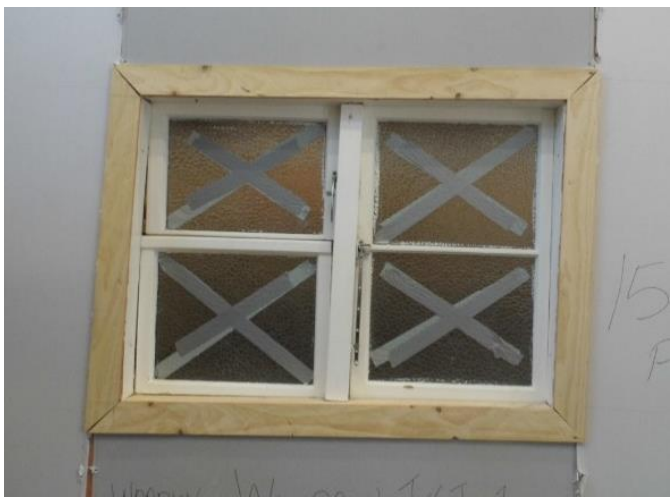

Figure 9: Example of Criteria 3 damage. 


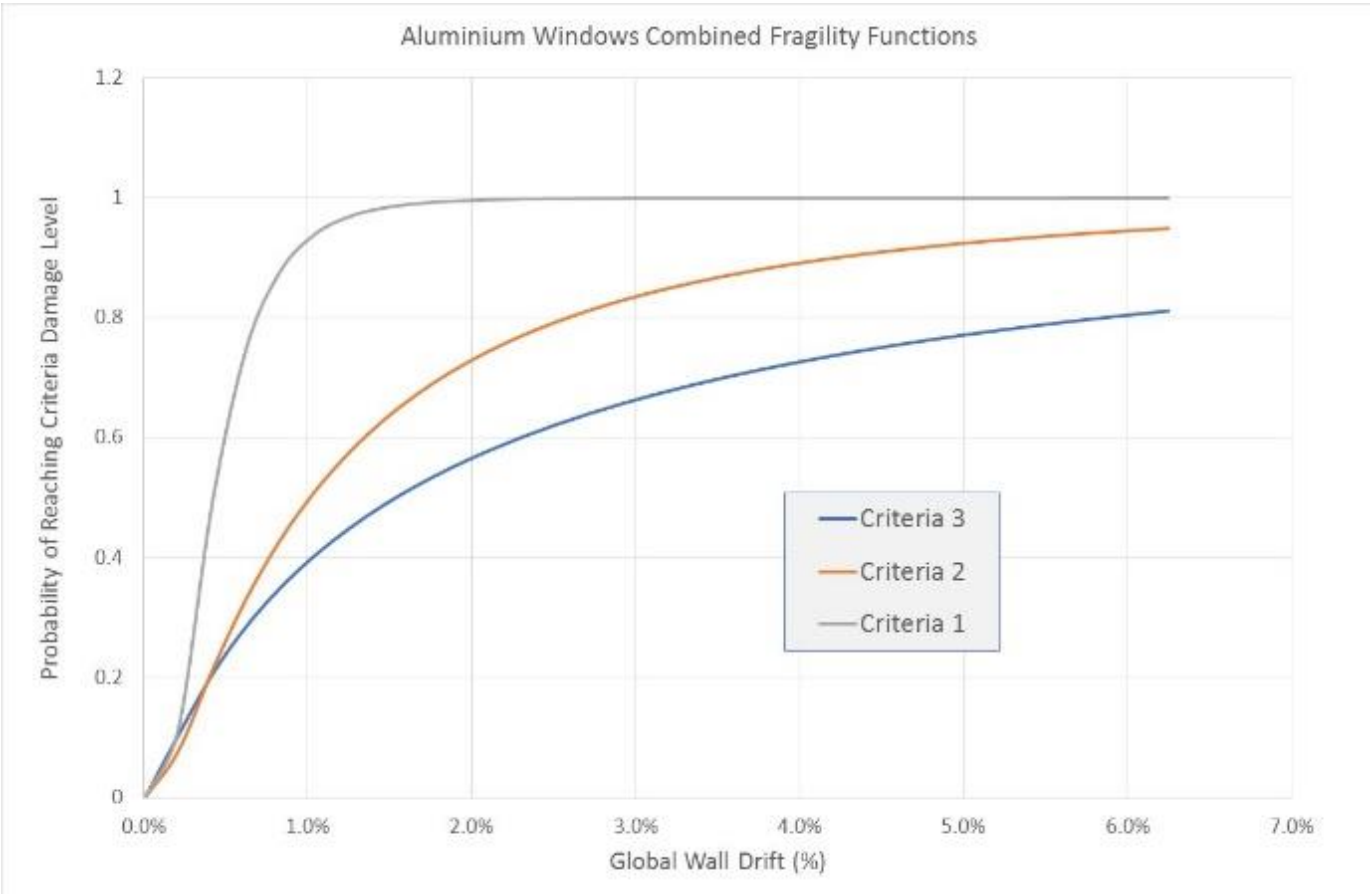

Figure 10: Fragility functions for aluminium residential windows.

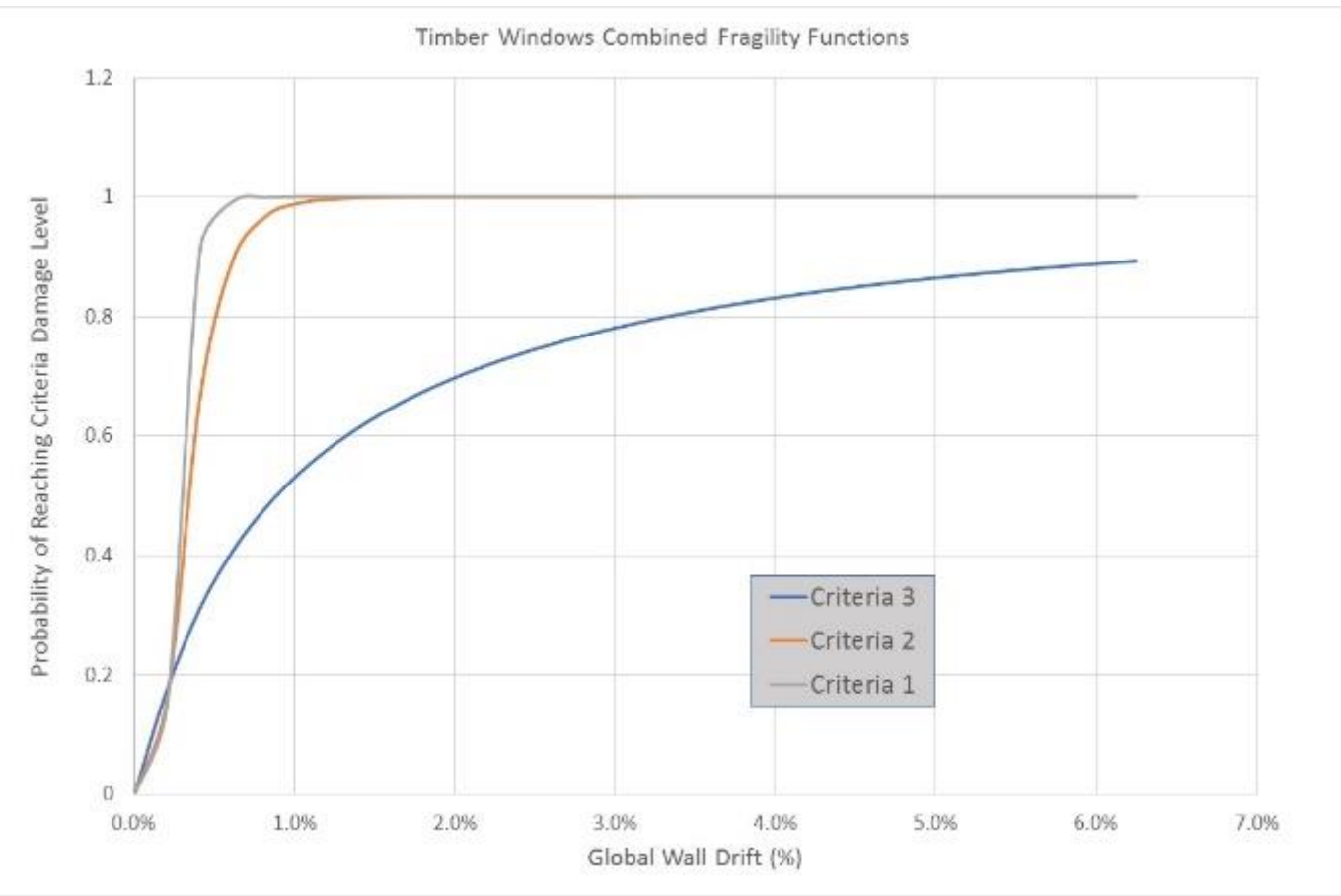

Figure 11: Fragility functions for wooden residential windows.

Table 1: Window fragility test data.

\begin{tabular}{|c|c|c|c|c|c|c|c|}
\hline $\begin{array}{c}\text { Aluminium } \\
\text { Specimen }\end{array}$ & $\begin{array}{c}\text { Criteria } 1 \\
\text { Displacement } \\
(\mathrm{mm})\end{array}$ & $\begin{array}{c}\text { Criteria } 2 \\
\text { Displacement } \\
(\mathrm{mm})\end{array}$ & $\begin{array}{c}\text { Criteria } 3 \\
\text { Displacement } \\
(\mathrm{mm})\end{array}$ & $\begin{array}{l}\text { Wooden } \\
\text { Specimen }\end{array}$ & $\begin{array}{c}\text { Criteria } 1 \\
\text { Displacement } \\
(\mathrm{mm})\end{array}$ & $\begin{array}{c}\text { Criteria } 2 \\
\text { Displacement } \\
(\mathrm{mm})\end{array}$ & $\begin{array}{c}\text { Criteria } 3 \\
\text { Displacement } \\
(\mathbf{m m})\end{array}$ \\
\hline 1 & 6 & 20 & 37 & 1 & 6 & 6 & 20 \\
\hline 2 & 9 & 21 & 32 & 2 & 7 & 11 & 23 \\
\hline 3 & 19 & 34 & 42 & 3 & 5 & 8 & 21 \\
\hline Mean & 11 & 25 & 37 & Mean & 6 & 8 & 21 \\
\hline Std. Dev. & 7 & 8 & 5 & Std. Dev. & 1 & 3 & 2 \\
\hline
\end{tabular}


It is worth noting that the results from these tests are clearly influenced by the stiffness of the walls and the methods of construction used. All specimens were constructed to be as representative as possible of New Zealand residential construction, but due to the variations that are inherent in these buildings it is difficult to capture all the possible permutations. This is also the case with the windows selected in that different windows, for instance full-height windows, may provide different results and would require additional testing and research.

\section{SUMMARY AND CONCLUSIONS}

Experimental racking testing on three aluminium and three wooden framed window systems installed into conventional residential light timber frame walls provided quantitative and qualitative data on the behaviour of these windows when subjected to lateral displacements. These displacements are representative of those experienced during earthquakes of varying intensity. Fragility functions for the two window types were developed and provide some ability to predict levels of damage that will occur to residential windows during an earthquake and also potential levels of repairs that will be required in order to ensure these wall systems maintain their weather tightness and durability as originally designed and constructed.

In general, the specimens tested showed significant resilience against glass failure and breakage, which suggests that there is considerable flexibility within the window systems to avoid glass shattering resulting in building envelope violation and possible occupant harm or death. Conversely, identified criteria damage was observed at relatively low levels of drift, which indicate that while resistance to glass failure was high, it is possible that weather-tightness and operability of the windows could be compromised and require repair following a much lower intensity earthquake. It should be noted that the damage criteria were observed when specimens were held at the prescribed displacement levels not at the zero point, so the damage observed assumes that there is some permanent drift in the wall and that the building has not returned to its original position.

Fragility functions for the two window types indicate that wooden framed windows are more likely to be damaged at lower drift levels than aluminium framed windows in residential walls. For both types of windows there is a high probability of gaps occurring in the frames at low drift levels, even in the realm of serviceability limit states, and this can potentially allow water ingress and affect the durability of timber structural systems. Because light timber framing is an inherently flexible structural system, it is feasible that by increasing the stiffness of the walls it would be possible to decrease window damage and reduce potential weathertightness issues after an earthquake. Stiffening the walls would likely be outside the scope of NZS 3604 and would therefore require some specific engineering design solutions to be investigated.

This project has provided a better understanding for predicting the performance of residential windows in New Zealand when subject to in-plane wall deformations. Designers can make use of these fragility functions to inform decisions regarding wall stiffness, building ductility and acceptable drift limits. While the tested systems had significant resilience in terms of ultimate limit state failures, there were numerous instances of significant non-structural damage that occurred at a drift levels associated with serviceability limit states that require some additional investigation. Wall and window stiffness (aspect ratio) can have an effect on the displacements of residential wall systems subject to in-plane loading and need to be taken into consideration when using the results of this research if systems are significantly different from those tested.

\section{RECOMMENDATIONS FOR FUTURE RESEARCH}

Testing of residential window systems was conducted and data analysed to develop fragility functions as previously described. Additional research work could likely provide improved understanding of these systems by incorporating methods that are more quantitative rather than relying on visual observations of damage. This additional testing could incorporate weathertightness testing of the wall panels following the displacements as has been done for commercial glazing systems that were tested at the University of Canterbury as part of a larger research project on improving the seismic performance of glazing and windows [12].

Different types of cladding could also result in different window system performance and would be worthwhile investigating using similar methods. Cladding systems were intentionally omitted from this project with the hope of providing generic results, even though they may be somewhat conservative.

Additional specimens could also be tested and included within the data set to improve the predictive strength of the developed fragility functions. Additional displacement data could also be included to improve understanding about the displacements occurring to the windows themselves during cyclic loading, as opposed to the global drift in the walls.

\section{ACKNOWLEDGMENTS}

This research project was funded by the Natural Hazards Research Platform and was administered through the University of Canterbury Department of Civil and Natural Resource Engineering. The authors would like to thank Tim Sullivan and Rajesh Dhakal of the University of Canterbury for their valuable input throughout the project.

\section{REFERENCES}

1 Baird A, Palermo A and Pampanin S (2011). "Façade Damage Assessment of Multi-Storey Buildings in the 2011 Christchurch Earthquake". Bulletin of the New Zealand Society for Earthquake Engineering, 44(4): 368-376. https://doi.org/10.5459/bnzsee.44.4.368-376

2 Dhakal RP (2010). "Damage to Non-Structural Components and Contents in 2010 Darfield Earthquake". Bulletin of the NZ Society for Earthquake Engineering, 43(4): 404-410. https://doi.org/10.5459/bnzsee.43.4.404$\underline{410}$

3 Wright PD (1989). "The Development of a Procedure and Rig for Testing the Racking Resistance of Curtain Wall Glazing". BRANZ Study Report No. 17, BRANZ Ltd, Judgeford, New Zealand.

4 Lim KYS and King AB (1991). "The Behaviour of External Glazing Systems under Seismic In-plane Racking”. BRANZ Study Report No. 39, BRANZ Ltd, Judgeford, New Zealand.

5 Thurston SJ and King AB (1992). "Two-directional Cyclic Racking of Corner Curtain Wall Glazing". BRANZ Study Report No. 44, BRANZ Ltd, Judgeford, New Zealand.

6 Carradine D, Beattie G, Finnegan J, Brunsdon D, Lee B and McGuigan D (2016). "Full-Scale Building and Wall Testing to Evaluate Lateral Load Performance of Existing Timber Framed School Buildings in New Zealand". Proceedings of the 2016 World Conference on Timber Engineering, Vienna, Austria.

7 O'Brien WC, Memari AM, Kremer PA and Behr RA (2012). "Fragility Curves for Architectural Glass in StickBuilt Glazing Systems”. Earthquake Spectra, 28(2): 639665. https://doi.org/10.1193/1.4000011 
8 Standards New Zealand (2011). "NZS 3604:2011 TimberFramed Buildings". Standards New Zealand, Wellington.

9 New Zealand Technical Correspondence Institute (1986). "Carpentry". VR Ward, Government Printer, Wellington.

10 Shelton R (2010). "A Wall Bracing Test and Evaluation Procedure". BRANZ Technical Paper P21. BRANZ Ltd, Judgeford, New Zealand. http://www.branz.co.nz/P21

11 Porter K, Kennedy R and Bachman R (2007). "Creating Fragility Functions for Performance-Based Earthquake
Engineering”. Earthquake Spectra, 23(2): 471-489. https://doi.org/10.1193/1.2720892

12 Arifin F, Sullivan T and Dhakal RP (2020). "Experimental Investigation into the Seismic Fragility of a Commercial Glazing System". Bulletin of the New Zealand Society for Earthquake Engineering, 53(3): 144-149. https://doi.org/10.5459/bnzsee.53.3.144-149 